\title{
Characterization of the DGAT1 Mutations and the CSN1S1 Promoter in the German Angeln Dairy Cattle Population
}

\author{
K. Sanders, ${ }^{\star}$ J. Bennewitz, ${ }^{\star 1}$ N. Reinsch,† G. Thaller, ${ }^{\star}$ E.-M. Prinzenberg,‡ C. Kühn,† and E. Kalm* \\ *Institute of Animal Breeding and Husbandry, Christian-Albrechts-University of Kiel, D-24098 Kiel, Germany \\ †Research Institute for Biology of Farm Animals, D-18196 Dummerstorf, Germany \\ łlnstitute of Animal Breeding and Genetics, University of Gießen, D-35390 Gießen, Germany
}

\section{ABSTRACT}

The identification of quantitative trait loci (QTL) and genes with influence on milk production traits has been the objective of various mapping studies in the last decade. In the centromeric region of Bos taurus autosome (BTA) 14, the acyl-CoA:diacylglycerol acyltransferase1 gene (DGAT1) has been identified as the most likely causative gene underlying a QTL for milk fat yield and content. Recently, a second polymorphism in the promoter of DGAT1 emerged as an additional source of variation. In this study, the frequencies and the effects of alleles at the DGAT1 K232A and at the $D G A T 1$ promoter variable number of tandem repeat (VNTR) locus on BTA14, and of alleles at the CSN1S1 ( $\alpha_{\mathrm{S} 1}$-casein-encoding gene) promoter on BTA6 in the German Angeln dairy cattle population were investigated. Analyzed traits were milk, fat, protein, lactose, and milk energy yield, fat, protein, lactose, and milk energy content and somatic cell score. The lysine variant of the DGAT1 K232A mutation showed significant effects for most of the milk production traits. A specific allele of the DGAT1 promoter VNTR showed significant effects on the traits lactose yield and content, milk energy content, and SCS compared with the other alleles. Additionally, a regulation mechanism between the DGAT1 K232A mutation and the DGAT1 promoter VNTR was found for fat yield and content, which could be caused by an upper physiological bound for the effects of the DGAT1 gene. At the CSN1S1 promoter, 2 of 4 alleles showed significant allele substitution effects on the milk yield traits.

Key words: $D G A T 1$, casein promoter, dairy cattle

\section{INTRODUCTION}

In the last decade, different QTL for milk production traits have been mapped in various dairy cattle populations (reviewed by Bovenhuis and Schrooten, 2002;

Received December 13, 2005.

Accepted March 20, 2006.

${ }^{1}$ Corresponding author: jbennewitz@tierzucht.uni-kiel.de
Khatkar et al., 2004). A segregating QTL with strong effects for milk production traits, especially for fat content in the centromeric region of Bos taurus autosome 14 (BTA14) was fine-mapped to a 3-cM region by Riquet et al. (1999) and later by Farnir et al. (2002). Subsequent studies identified a nonconservative dinucleotide substitution (K232A) in the acyl-CoA:diacylglycerol acyltransferase1 (DGAT1) gene at positions 10,433 and 10,434 in exon number VIII as the most likely mechanism underlying the QTL on this chromosome (Grisart et al., 2002; Winter et al., 2002). The DGAT1 gene encodes the DGAT1 enzyme, which catalyzes the final step of the triglyceride synthesis. The DGAT1 lysine variant increases fat and protein content, as well as fat yield, whereas the DGAT1 alanine variant increases milk and protein yield (e.g., Grisart et al., 2002; Winter et al., 2002; Thaller et al., 2003). In an expression study, it was shown that there is a small difference in the expression level of mRNA derived from bovine mammary gland tissue for the $2 D G A T 1$ variants, which is due to the structural mutation at K232A (Grisart et al., 2004). A difference in the enzyme activity level (measured as $\mathrm{V}_{\max }$ ) in producing triglycerides was observed between the 2 variants, with $\mathrm{V}_{\max }$ being higher for the lysine variant (Grisart et al., 2004).

In subsequent studies, at least one additional source of variation besides the diallelic DGAT1 K232A mutation was postulated to be responsible for the QTL in the centromeric region at BTA14 (Winter et al., 2002; Bennewitz et al., 2004). In the German Holstein population, Kühn et al. (2004) described 5 alleles at a variable number of tandem repeat (VNTR) polymorphism in the DGAT1 promoter, which showed an effect on fat content additional to the DGAT1 K232A mutation.

Besides the centromeric region of BTA14, the casein cluster on BTA6 is a genomic region where several QTL have been postulated for milk production traits. Some studies investigated the effects of the casein cluster on BTA6 with special emphasis on protein content in different dairy cattle breeds (Velmala et al., 1999; Ron et al., 2001; Olsen et al., 2005). Prinzenberg et al. (2003) observed associations between milk production traits and $\alpha_{\mathrm{S} 1}$-casein encoding gene (CSN1S1) variants in the 
5 -flanking region in the German Holstein population. The authors reported a superior effect of allele 4 compared with all other alleles. In a recent study, Kuss et al. (2005) reported an $\mathrm{A} \rightarrow \mathrm{G}$ exchange at position -175 $\mathrm{bp}$ in the promoter region of the bovine $\alpha_{\mathrm{S} 1}$-caseinencoding gene. Animals carrying the $\mathrm{G}$ variant showed higher milk content traits and a higher quantity of $\alpha_{\mathrm{S1}}$-casein compared with the animals carrying the $\mathrm{A}$ variant. The authors argued that the $\mathrm{G}$ variant might be involved in the regulation mechanism of the CSN1S1 expression.

The main objective of this study was the characterization of the evidence, of the frequencies and of the effects of the alleles at the DGAT1 K232A mutation, the $D G A T 1$ promoter VNTR, and the CSN1S1 promoter in the German Angeln population. The Angeln breed is located in the north of Germany. For several years, this breed has been crossed with different red breeds such as Red Holstein, Swedish Red and White, and Finnish Ayrshire (Savaş et al., 1998), which may result in a higher genetic variability compared with, for example, Holstein-Friesian. Among others, the characteristics of this breed are high milk protein and fat contents. In addition to the traditional milk production traits (milk, fat, and protein yield, fat and protein content, and SCS) the traits lactose yield and content and milk energy yield and content were included in the analysis.

\section{MATERIALS AND METHODS}

\section{Pedigree Information}

Initially, 5 families with a total of 805 daughters were selected for the genotyping process. The family size ranged between 123 and 199 daughters per sire with an average of 161 daughters. For the genotyping process, blood samples from the daughters and semen samples of the sires were used. No blood samples were available of the daughters' dams. A marker-assisted estimation of pedigree errors revealed $7 \%$ conflicting daughters (i.e., genotypes of daughters and of respective sires did not match; Sanders et al., 2006). These daughters were excluded from the analysis, and therefore, the total number of daughters included was 749 .

\section{Genotyping Data}

The 5 families were genotyped for the DGAT1 K232A mutation, the DGAT1 promoter VNTR, and the CSN1S1 promoter. The genotyping of DGAT1 K232A was carried out by a PCR-RFLP test based on the K232A substitution at DGAT1 K232A. The following primers were used for the amplification of a 222-bp PCR fragment containing the DGAT1 K232A mutation (at position $10,433 / 10,434$ in exon number VIII) of the sequence
AY065621 (similar to the positions and numbers of GenBank; Grisart et al., 2002): DGAT1 $1_{6994 \mathrm{~L} 22} 5^{\prime}$-GCGGGG GAAGTTGAGCTCGTAG-3' and DGAT1 ${ }_{6785 \mathrm{U} 30} 5^{\prime}$-CCT GACTGGCCGCCTGCCGCTTGCTCGTAG-3'. The 15$\mu \mathrm{L}$ PCR reaction consisted of $5 \mu \mathrm{L}(20 \mathrm{ng})$ of genomic DNA, 2 pmol of each primer, $1.5 \mathrm{mM} \mathrm{MgCl}_{2}, 0.2 \mathrm{mM}$ $\mathrm{dNTP}$, and 0.4 units of recombinant Taq polymerase (Invitrogen GmbH, Karlsruhe, Germany). The PCR fragment was digested by the restriction enzyme EaeI (CfrI; Amersham Pharmacia Biotech, Little Chalfont, UK) and was analyzed using the MegaBACE 500 Analysis System (Amersham Biosciences Europe GmbH, Freiburg, Germany). The uncut fragment (222 bp) represented the lysine variant (K232) and the cut fragment $(184 \mathrm{bp})$ represented the alanine variant $(232 \mathrm{~A})$. The lysine variant was denoted as the $K$ variant and the alanine variant as the $A$ variant.

The amplification of the DGAT1 promoter VNTR was conducted in a different way, as described by Kühn et al. (2004) because the primers used by Kühn et al. (2004) did not amplify in this study. One reason could be the GC-rich sequences of the primer pair used by Kühn et al. (2004), which were located in a region between 1439 and 1565 at the sequence AJ318490. The amplification of a DGAT1 promoter VNTR fragment comprised the repeat region between 1421 and 1666 of the DGAT1 sequence AJ318490 (similar to the positions and numbers of GenBank; Winter et al., 2002). The PCR was carried out with the following primers: DGAT $1_{1421 \mathrm{U} 21}$ 5'-ACCCTGGCAGCACCTCAATCA-3' and DGAT1 $1_{1643 \mathrm{~L} 24} 5^{\prime}$-CAATGAGAAGGCACGGACTGT GAA-3'. The primers were designed by using the Primer3 program (Rozen and Skaletsky, 2000). The characteristic of these primers is a high melting point $\left(\mathrm{T}_{\mathrm{m}}\right)$, taking the GC-rich template into account. The 10$\mu \mathrm{L}$ PCR reaction consisted of $3 \mu \mathrm{L}(20 \mathrm{ng})$ of genomic DNA, 3 pmol of each primer, $1 \mathrm{~m} M \mathrm{MgCl}_{2}, 0.3 \mathrm{~m} M$ dNTP, and 0.125 units of Platinum Pfx DNA polymerase (Invitrogen $\mathrm{GmbH}$, Karlsruhe, Germany). This polymerase works with a $\mathrm{PCR}_{\mathrm{X}}$ Enhancer System, which facilitates efficient amplification of GC-rich sequences. The electrophoresis was carried out using the ABI377 (Applied Biosystems, Darmstadt, Germany). At the DGAT1 promoter VNTR, 6 alleles were found, which were denoted as VNTR alleles A, B, C, D, E, and $\mathrm{F}$, respectively; VNTR allele $\mathrm{F}$ was only present in 2 unrelated daughters and was excluded from the statistical analysis. The genotyping of the CSN1S1 promoter was carried out as described by Prinzenberg et al. (2003), and the alleles at this promoter were denoted in accordance with that study. Genotypes were stored in the ADRDB database (Reinsch, 1999) and were checked for agreement with Mendelian laws of inheri- 
tance using the program GENCHECK (Bennewitz et al., 2002).

\section{Phenotypic Data}

Yield deviations (YD; Wiggans and VanRaden, 1991) were used as the phenotypic units of measurement. For the traits milk yield, fat yield, protein yield, and SCS, YD were taken from the August 2004 routine national breeding evaluation for the Angeln breed (VIT, Verden, Germany). No YD were calculated in the routine national breeding evaluation for fat and protein content, milk energy yield and content, as well as lactose yield and content. Therefore, YD for fat and protein content were calculated by using the following formula (in accordance with VIT, 2003), illustrated for protein content:

YD $($ protein content $)=$

$\mathrm{YD}$ (protein content) $\times 100-\mathrm{YD}($ milk yield $) \times \mathrm{PM}$ (protein content) YD (milk yield) + PM (milk yield)

where $\mathrm{PM}$ is the population mean. For those traits that are not routinely evaluated, REML-estimates for genetic parameters were first estimated by using a fixedregression test-day model (N. Reinsch and J. Bennewitz, unpublished data), and these estimates were subsequently used to obtain YD for lactose yield and content as well as milk energy yield and content. Milk energy yield of a cow can be estimated from milk protein, milk fat, and milk lactose yield (Nostitz and Mielke, 1995); subsequently, the milk energy content estimation is straightforward. The YD for the first 3 lactations were evaluated as a weighted average (see Appendix).

\section{Statistical Analyses Using Weighted Regressions}

Statistical analyses were carried out using a weighted regression approach. Because it can reasonably be assumed that the mutations considered in this study (i.e., DGAT1 K232A, DGAT1 VNTR, and CSN1S1) are either causative or in a strong linkage disequilibrium with the causative gene, all regressions were performed across families taking the fixed effects of the corresponding sire into account. Weights for the observations were the reciprocal of the variance of the YD (see Appendix). The regressions always included the fixed effect of the sire and putative additional relationships between daughters within a half-sib family (e.g., daughters having the same dam or the same maternal grandsire) are not accounted for. The applied models are described below for each considered mutation.

\section{Statistical Analyses Regarding DGAT1}

Allele frequencies of DGAT1 K232A and the DGAT1 promoter VNTR were estimated using a maximum-likelihood procedure (for more details, see Sanders et al., 2006).

The allele substitution effects of the $\mathrm{K}$ variant at DGAT1 K232A were estimated as follows:

$$
\mathrm{y}_{\mathrm{ij}}=\mathrm{s}_{\mathrm{i}}+\mathrm{b}_{1} \times \mathrm{x}_{\mathrm{ij}}+\mathrm{e}_{\mathrm{ij}} \text {, }
$$

where $y_{i j}=$ the phenotype of the $j$ th daughter of the $i$ th sire, $\mathrm{s}_{\mathrm{i}}=$ the fixed effect of the $i$ th sire, $\mathrm{x}_{\mathrm{ij}}=$ the number of copies $(0,1,2)$ of the $\mathrm{K}$ variant of the $j$ th daughter of the $i$ th sire, and $\mathrm{e}_{\mathrm{ij}}=$ the random residual effect. The regression coefficient $b_{1}$ represents the allele substitution effect of the $\mathrm{K}$ variant.

Additionally, it was possible to estimate putative dominance effects at DGAT1 K232A because, in contrast to a granddaughter design, there were genotype and phenotype information recorded at the same animals. The dominance effects were estimated by treating the number of copies $(0,1,2)$ of the $\mathrm{K}$ variant as classification variables in model [1]. We tested whether the least squares means of the heterozygous animals were midway between those of the homozygous animals.

The allele substitution effects of the different alleles (A to E) at the DGAT1 promoter VNTR were estimated by multiple regression on the number of copies of the $\mathrm{K}$ variant at DGAT1 K232A and on the number of copies of the respective VNTR allele:

$$
\begin{aligned}
\mathrm{y}_{\mathrm{ij}}= & \mathrm{s}_{\mathrm{i}}+\mathrm{b}_{1} \times \mathrm{x}_{\mathrm{ij}}+\mathrm{b}_{\mathrm{A}} \times \mathrm{z}_{\mathrm{A}, \mathrm{ij}}+\mathrm{b}_{\mathrm{B}} \times \mathrm{z}_{\mathrm{B}, \mathrm{ij}}+\mathrm{b}_{\mathrm{C}} \\
& \times \mathrm{z}_{\mathrm{C}, \mathrm{ij}}+\mathrm{b}_{\mathrm{D}} \times \mathrm{z}_{\mathrm{D}, \mathrm{ij}}+\mathrm{b}_{\mathrm{E}} \times \mathrm{z}_{\mathrm{E}, \mathrm{ij}}+\mathrm{e}_{\mathrm{ij}},
\end{aligned}
$$

where $\mathrm{z}_{\mathrm{A}-\mathrm{E}, \mathrm{ij}}$ is the number of copies $(0,1,2)$ of the respective allele (A to E) at the DGAT1 promoter VNTR of the $j$ th daughter of the $i$ th sire, and $b_{i}$ is the respective regression coefficient. To avoid dependencies in the coefficient matrix, the effect of the VNTR allele $\mathrm{E}$ was set to zero. This model resulted in significant effects of the VNTR allele E compared with the other alleles and for that reason, its effect was reestimated by applying the following simplified model:

$$
\mathrm{y}_{\mathrm{ij}}=\mathrm{s}_{\mathrm{i}}+\mathrm{b}_{1} \times \mathrm{x}_{\mathrm{ij}}+\mathrm{b}_{\mathrm{E}} \times \mathrm{z}_{\mathrm{E}, \mathrm{ij}}+\mathrm{e}_{\mathrm{ij}} \text {, }
$$

where $b_{E}=$ the regression coefficient presenting the substitution effect of the VNTR allele E compared with all other alleles (Falconer and Mackay, 1996).

The haplotypes of DGAT1 K232A and of the DGAT1 promoter VNTR of the 5 sires were derived from the genotypes of their respective daughters. Subsequently, the haplotypes of the daughters were determined using 
the haplotypes of their sires, under the assumption that no recombination occurs between DGAT1 K232A and the DGAT1 promoter VNTR. The different haplotypes were denoted as $\mathrm{KO}, \mathrm{KE}, \mathrm{AO}$, and $\mathrm{AE}$, where $\mathrm{O}$ presents all other alleles at the DGAT1 promoter VNTR, excluding allele E. Maximum-likelihood estimations of haplotype frequencies were carried out as described by Sanders et al. (2006). To include daughters whose haplotypes cannot be unequivocally derived, an estimation of the posterior probability for the possible haplotypes was carried out (Appendix B). The substitution effects of the different haplotypes were estimated using the following model:

$$
\mathrm{y}_{\mathrm{ij}}=\mathrm{s}_{\mathrm{i}}+\mathrm{b}_{\mathrm{xz}} \times \mathrm{h}_{\mathrm{xz}, \mathrm{ij}}+\mathrm{e}_{\mathrm{ij}},
$$

where $\mathrm{s}_{\mathrm{i}}=$ the fixed effect of the sire $\mathrm{i}, \mathrm{b}_{\mathrm{xz}}=$ the respective regression coefficient, and $\mathrm{h}_{\mathrm{xz}, \mathrm{ij}}=$ the number of copies $(0,1,2)$ of the respective haplotype of the $j$ th daughter of the $i$ th sire. The indices $\mathrm{x}$ and $\mathrm{z}$ represent the respective alleles of the DGAT1 K232A mutation and of the DGAT1 promoter VNTR. Model [4] was applied for all 4 haplotypes in turn. In the case of equivocally derived haplotypes, the corresponding posterior probabilities were used as the regression variables. To test whether the effects of the haplotypes are additive, model [4] was applied, but the number of copies of the haplotypes was treated as a classification variable. Therefore, only the unequivocally derived haplotypes were used. The comparison of the respective least squares means of the haplotype classes reveal a putative nonadditivity.

Similarly, the existence of a putative interaction between the DGAT1 K232A mutation and the DGAT1 promoter VNTR was determined by:

$$
\mathrm{y}_{\mathrm{ij}}=\mathrm{s}_{\mathrm{i}}+\mathrm{b}_{1} \times \mathrm{x}_{\mathrm{ij}}+\mathrm{b}_{\mathrm{E}} \times \mathrm{z}_{\mathrm{E}, \mathrm{ij}}+\mathrm{b}_{\mathrm{xz}} \times \mathrm{h}_{\mathrm{xz}, \mathrm{ij}}+\mathrm{e}_{\mathrm{ij}} .
$$

The regression variable $h_{x z, i j}$ represents a putative interaction. For xz, all 4 haplotypes were used in turn. In the next step, a putative interaction between the haplotypes was tested using the following model:

$$
\begin{gathered}
y_{i j}=s_{i}+h_{x z, i j}+b_{x^{\prime} z^{\prime}} \times h_{x^{\prime} z^{\prime}, i j}+\omega_{x z x^{\prime} z^{\prime}, i j} \\
\times h_{x^{\prime} z^{\prime}, i j}+e_{i j},
\end{gathered}
$$

where $h_{x z, i j}$ is the fixed effect of the haplotype $x z$ (i.e., the number of copies of the haplotype is modeled as a classification variable) and $\omega_{\mathrm{xzx}^{\prime} z^{\prime}, \mathrm{ij}}$ is the interaction of the haplotypes $\mathrm{xz}$ and $\mathrm{x}^{\prime} \mathrm{z}^{\prime}$. This model tested whether the regression coefficient $b_{\mathrm{x}^{\prime} z^{\prime}}$ of the haplotype $x^{\prime} z^{\prime}$ depended on the number of copies (either 0 or 1 ) of the haplotype xz carried by a daughter. All possible haplotype combinations were tested in turn $\left(x^{\prime} z^{\prime} \neq x z\right)$.

\section{Statistical Analysis Regarding CSN1S1}

The allele frequencies of the CSN1S1 promoter were estimated with the same maximum-likelihood function as the DGAT1 mutations.

A multiple weighted regression model was applied. Because of the highly significant effect of DGAT1 K232A, the model estimated the allele substitution effect of the different alleles (1 to 4 ) at the CSN1S1 promoter by simultaneous regression on the number of copies $(0,1,2)$ of the alleles at the CSN1S1 promoter and on the number of copies of the $\mathrm{K}$ variant at DGAT1 K232A. This analysis was carried out twice; at first the effects of the CSN1S1 allele 2 were set to zero and afterwards the effects of the CSN1S1 allele 3 were set to zero. The following model was applied:

$$
\begin{gathered}
\mathrm{y}_{\mathrm{ij}}=\mathrm{s}_{\mathrm{i}}+\mathrm{b}_{1} \times \mathrm{x}_{\mathrm{ij}}+\mathrm{b}_{\mathrm{v} 1} \times \mathrm{v}_{1, \mathrm{ij}}+\mathrm{b}_{\mathrm{v} 2} \times \mathrm{v}_{2, \mathrm{ij}}+\mathrm{b}_{\mathrm{v} 3} \\
\times \mathrm{v}_{3, \mathrm{ij}}+\mathrm{b}_{\mathrm{v} 4} \times \mathrm{v}_{4, \mathrm{ij}}+\mathrm{e}_{\mathrm{ij}},
\end{gathered}
$$

where $b_{\mathrm{vn}}$ is the respective regression coefficient of the respective allele at the CSN1S1 promoter of the $j$ th daughter of the $i$ th sire, and $\mathrm{v}_{\mathrm{n}, \mathrm{ij}}$ is the number of copies $(0,1,2)$ of the respective allele at the CSN1S1 promoter. The remaining terms are the same as in model [1]. The results of this model revealed a significant effect of the CSN1S1 alleles 2 and 3 for the different milk production traits. Therefore, the following simplified model was applied:

$$
y_{i j}=s_{i}+b_{1} \times x_{i j}+b_{v 2} \times v_{2, i j}+e_{i j} .
$$

The regression coefficient $b_{\mathrm{v} 2}$ presents the allele substitution effect of the CSN1S1 allele 2 compared with all other alleles. The same model was applied for the CSN1S1 allele 3. Test for a putative interaction between DGAT1 K232A and CSN1S1 allele 2 and 3, respectively, was conducted using the following model (illustrated for CSN1S1 allele 2):

$$
\mathrm{y}_{\mathrm{ij}}=\mathrm{s}_{\mathrm{i}}+\mathrm{x}_{\mathrm{ij}}+\mathrm{b}_{\mathrm{v} 2} \times \mathrm{v}_{2, \mathrm{ij}} \times \omega_{\mathrm{xv} 2, \mathrm{ij}} \times \mathrm{v}_{2, \mathrm{ij}}+\mathrm{e}_{\mathrm{ij}},
$$

where $\mathrm{x}_{\mathrm{ij}}$ is the fixed effect of the DGAT1 K232A genotype (i.e., the number of copies of the $\mathrm{K}$ variant is modeled as a classification variable) and $\omega_{\mathrm{xv} 2, \mathrm{ij}}$ is the interaction of the DGAT1 K232A and the CSN1S1 allele 2.

\section{RESULTS}

\section{Allele Frequencies and Haplotype Frequencies}

Table 1 presents the allele frequencies of the DGAT1 K232A mutation, the DGAT1 promoter VNTR, and the CSN1S1 promoter. The allele frequency of the $\mathrm{K}$ variant 
Table 1. Allele frequencies of DGAT1 K232A, the DGAT1 promoter variable number of tandem repeat (VNTR), and the CSN1S1 promoter

\begin{tabular}{|c|c|c|c|c|c|}
\hline \multicolumn{2}{|c|}{ DGAT1 K232A } & \multicolumn{2}{|c|}{$D G A T 1$ promoter VNTR } & \multicolumn{2}{|c|}{ CSN1S1 promoter } \\
\hline Allele $^{1}$ & Frequency & Allele & Frequency & Allele & Frequency \\
\hline K & 0.61 & A & 0.01 & 1 & 0.01 \\
\hline \multirow[t]{5}{*}{ A } & 0.39 & $\mathrm{~B}$ & 0.25 & 2 & 0.70 \\
\hline & & $\mathrm{C}$ & 0.30 & 3 & 0.20 \\
\hline & & D & 0.06 & 4 & 0.09 \\
\hline & & $\mathrm{E}$ & 0.38 & & \\
\hline & & $\mathrm{F}$ & $<0.01$ & & \\
\hline
\end{tabular}

${ }^{1} \mathrm{~K}$ denotes the lysine variant and $\mathrm{A}$ the alanine variant.

at DGAT1 K232A was 0.61 . Three sires were heterozygous at DGAT1 K232A and 2 were homozygous for the $\mathrm{K}$ variant. The most frequent DGAT1 promoter VNTR allele in the Angeln population was the VNTR allele E (0.38). In the case of the CSN1S1 promoter, 4 alleles were segregating in the Angeln dairy cattle population, which is in accordance with Prinzenberg et al. (2003). The most frequent CSN1S1 allele in this population was allele 2. Three sires were homozygous for this allele. The frequencies of the haplotypes of the DGAT1 $K 232 A$ and of the DGAT1 promoter VNTR are listed in Table 2. The most frequent haplotypes were the haplotypes $\mathrm{KE}$ and $\mathrm{AO}$ (0.38), whereas the frequency of the haplotype AE was very low (0.01). Indeed, these haplotype frequencies indicate that there was information available to separate the effects of the DGAT1 K232A and DGAT1 VNTR allele E.

\section{Allele Substitution Effects of DGAT1 K232A and of DGAT1 Promoter VNTR}

Average allele substitution effects of the $\mathrm{K}$ variant at DGAT1 K232A for the 10 milk production traits are shown in Table 3 (results of model [1]). For the content traits protein, fat, and milk energy content, as well as for fat yield, positive effects of the $\mathrm{K}$ variant were observed. The $\mathrm{K}$ variant showed stronger allele substitution effects for fat and milk energy content than for

Table 2. Haplotype frequencies of DGAT1 K232A and DGAT1 promoter variable number of tandem repeat (VNTR)

\begin{tabular}{lll}
\hline $\begin{array}{l}\text { Haplotypes } \\
\text { DGAT1 K232A } \\
\text { and DGAT1 } \\
\text { promoter VNTR }^{1}\end{array}$ & $\begin{array}{l}\text { Haplotype } \\
\text { abbreviation }^{2}\end{array}$ & \\
\hline K232-O & KO & Frequency \\
K232-E & KE & 0.23 \\
$232 \mathrm{~A}-\mathrm{O}$ & $\mathrm{AO}$ & 0.38 \\
$232 \mathrm{~A}-\mathrm{E}$ & $\mathrm{AE}$ & 0.38 \\
\hline
\end{tabular}

${ }^{1}$ All VNTR alleles except VNTR allele E were combined into one group (denoted as $\mathrm{O}$ ).

${ }^{2}$ As used in the text. protein content. Negative effects were observed for the yield traits milk, protein, and lactose yield. The allele substitution effects of the $\mathrm{K}$ variant for milk ( $\alpha=-87.69$ $\mathrm{kg}, P<0.001)$, fat $(\alpha=3.21 \mathrm{~kg}, P<0.001)$, and protein yield $(\alpha=-1.31 \mathrm{~kg}, P=0.016)$ were expected because of the results of previous studies (e.g., Spelman et al., 2002; Thaller et al., 2003; Bennewitz et al., 2004). The estimation of the dominance effects of the DGAT1 $K 232 \mathrm{~A}$ alleles for the traits milk yield, lactose yield, milk energy content, and SCS showed that the least squares means of the heterozygous genotypes (AK) were between the 2 homozygotes, indicating that DGAT1 K232A did not show any dominance effects (data not shown).

Table 4 presents the allele substitution effects of the K variant at DGAT1 K232A and of the DGAT1 promoter VNTR allele $\mathrm{E}$ for the 10 milk production traits (results of model [3]). For the traits lactose content and SCS, the VNTR allele $\mathrm{E}$ and the $\mathrm{K}$ variant showed significant effects in the opposite direction. For the traits lactose yield and milk energy content, both the $\mathrm{K}$ variant and the VNTR allele E showed significant negative effects and significant positive effects, respectively. For the traits milk yield, protein content, fat yield, and fat content, only the $\mathrm{K}$ variant showed significant effects.

The substitution effects of the different haplotypes of DGAT1 K232A and the DGAT1 promoter VNTR are

Table 3. Allele substitution effects $(\alpha)$ of the $\mathrm{K}$ variant at DGAT1 $K 232 A$ with standard errors (SE), $F$-value, and $P$-value for the different milk production traits (results from model [1])

\begin{tabular}{lclrr}
\hline Trait & $\alpha$ & \multicolumn{1}{l}{$\mathrm{SE}$} & $F$-value & $P$-value \\
\hline Milk yield (kg) & -87.69 & 15.83 & 30.68 & $<0.001$ \\
Protein yield (kg) & -1.31 & 0.54 & 5.78 & 0.016 \\
Protein content (\%) & 0.03 & 0.004 & 59.23 & $<0.001$ \\
Fat yield (kg) & 3.21 & 0.84 & 14.51 & $<0.001$ \\
Fat content (\%) & 0.12 & 0.009 & 177.64 & $<0.001$ \\
Lactose yield (g) & -9.54 & 2.10 & 20.59 & $<0.001$ \\
Lactose content (\%) & 0.005 & 0.003 & 2.88 & 0.090 \\
Milk energy yield (ME) & 0.13 & 0.14 & 0.96 & 0.327 \\
Milk energy content (ME/kg) & 0.09 & 0.006 & 248.89 & $<0.001$ \\
SCS & -0.009 & 0.01 & 0.78 & 0.376 \\
\hline
\end{tabular}


Table 4. Allele substitution effects of the $\mathrm{K}$ variant at DGAT1 K232A and of the DGAT1 promoter variable number of tandem repeat (VNTR) allele $\mathrm{E}$ on the milk production traits, with standard error (SE) and $P$ values (results from model [3])

\begin{tabular}{|c|c|c|c|c|c|c|}
\hline \multirow[b]{2}{*}{ Trait } & \multicolumn{3}{|c|}{$\mathrm{K}$ variant } & \multicolumn{3}{|c|}{ VNTR allele E } \\
\hline & $\alpha$ & SE & $P$-value & $\alpha$ & $\mathrm{SE}$ & $P$-value \\
\hline Milk yield (kg) & -77.26 & 20.17 & $<0.001$ & -20.74 & 20.29 & 0.31 \\
\hline Protein yield (kg) & -0.98 & 0.69 & 0.155 & -0.68 & 0.70 & 0.33 \\
\hline Protein content (\%) & 0.03 & 0.005 & $<0.001$ & 0.002 & 0.005 & 0.75 \\
\hline Fat yield $(\mathrm{kg})$ & 3.59 & 1.07 & $<0.001$ & -0.71 & 1.08 & 0.52 \\
\hline Fat content (\%) & 0.12 & 0.01 & $<0.001$ & 0.007 & 0.01 & 0.54 \\
\hline Lactose yield (g) & -6.46 & 2.66 & 0.015 & -5.53 & 2.67 & 0.04 \\
\hline Lactose content $(\%)$ & 0.009 & 0.003 & 0.007 & -0.008 & 0.004 & 0.03 \\
\hline Milk energy yield (ME) & 0.30 & 0.17 & 0.088 & -0.29 & 0.17 & 0.10 \\
\hline Milk energy content (ME/kg) & 0.08 & 0.007 & $<0.001$ & 0.01 & 0.007 & 0.07 \\
\hline SCS & -0.03 & 0.01 & 0.038 & 0.03 & 0.01 & 0.04 \\
\hline
\end{tabular}

presented in Table 5 (results of model [4]). The results of the haplotype regression model support the results of the previous models (Tables 3 and 4 ). The haplotype KE showed significant negative effects for milk, protein, and lactose yield and positive effects for protein, fat, and milk energy content as well as fat yield. For the same traits, the haplotype AO showed effects in the opposite direction. For both haplotypes, no significant effects were observed for the traits milk energy yield, lactose content, and SCS. The effects of the haplotype $\mathrm{KO}$ were mainly in the same direction as those of the haplotype KE. The haplotype AE showed the highest effects for the main part of the traits. Because of the low number of daughters showing this haplotype (and no homozygous ones), the effects were mainly not significant and the standard deviations of estimates were high (Table 5).

\section{Interaction Between DGAT1 K232A and DGAT1 Promoter VNTR}

The least squares means of the 3 haplotype classes for the haplotypes $\mathrm{KE}$ and $\mathrm{AO}(0,1$, or 2 copies of the respective haplotype) are shown in Table 6. For haplotype $\mathrm{KE}$, differences between classes 0 and 1 were larger than the differences between 1 and 2, for the traits protein content, and fat yield and content. On the other hand, for haplotype AO, differences between classes 1 and 2 were larger compared with the differences between the classes 0 and 1 . These results show the nonadditivity of these haplotypes. In contrast, it was observed that the least squares means for the traits milk yield and lactose yield of haplotypes $\mathrm{KE}$ and $\mathrm{AO}$ for class 1 were approximately between the values of classes 0 and 2. For the other traits and haplotypes, no clear pattern regarding putative additivity was observed. This might be due either to nonsignificant effects of the haplotype for the respective trait (Table 5) or due to the low haplotype frequency (Table 2) and hence, due to the strong effect of the second haplotype of a daughter in case of a heterozygosity, or even in case of carrying no copies of the respective haplotype (haplotype classes 1 and 0 , respectively).

The results of model [5] revealed a statistically significant interaction effect between DGAT1 K232A and DGAT1 promoter VNTR for fat content, because all 3

Table 5. Substitution effects $(\alpha)$, standard errors (SE), and comparisonwise error probabilities ( $P$-value) of the different haplotypes of $D G A T 1$ K232A and the DGAT1 promoter variable number of tandem repeat on 10 milk production traits (results from model [4])

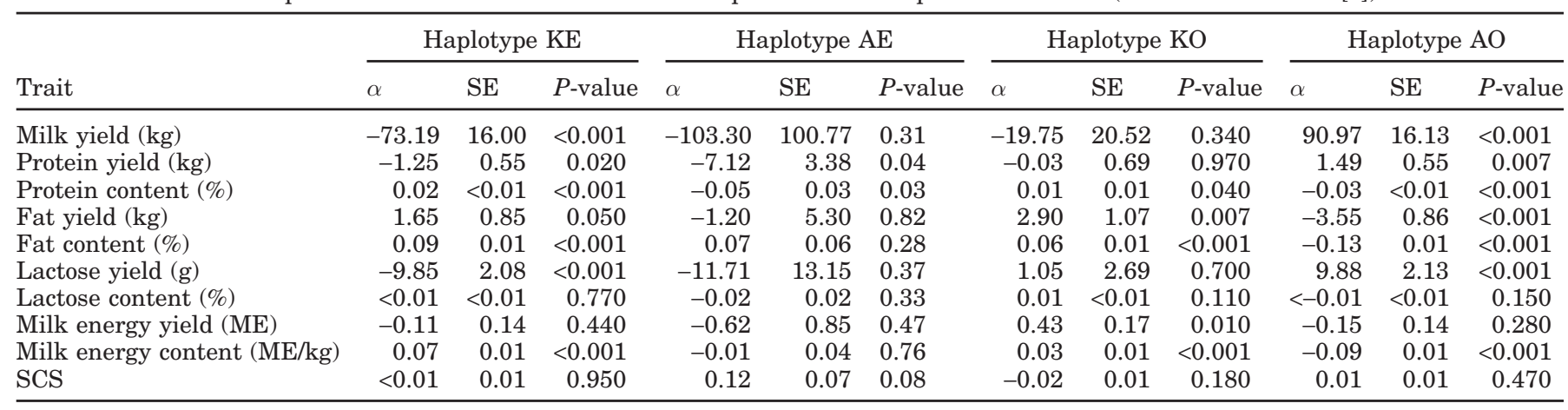


Table 6. Least squares means of the 3 haplotype classes $(0,1,2)$ for the haplotypes KE and AO (standard error in parentheses)

\begin{tabular}{|c|c|c|c|c|c|c|}
\hline \multirow[b]{2}{*}{ Trait } & \multicolumn{3}{|c|}{ Haplotype KE } & \multicolumn{3}{|c|}{ Haplotype AO } \\
\hline & Class 0 & Class 1 & Class 2 & Class 0 & Class 1 & Class 2 \\
\hline Milk yield (kg) & $\begin{array}{r}-133.30 \\
(16.29)\end{array}$ & $\begin{array}{r}-202.65 \\
(14.87)\end{array}$ & $\begin{array}{r}-268.90 \\
(31.74)\end{array}$ & $\begin{array}{r}-237.41 \\
(15.38)\end{array}$ & $\begin{array}{r}-147.36 \\
(15.68)\end{array}$ & $\begin{array}{c}-66.53 \\
(32.81)\end{array}$ \\
\hline Protein yield (kg) & $\begin{array}{c}0.47 \\
(0.55)\end{array}$ & $\begin{array}{c}-0.25 \\
(0.51)\end{array}$ & $\begin{array}{c}-2.22 \\
(1.08)\end{array}$ & $\begin{array}{c}-1.25 \\
(0.53)\end{array}$ & $\begin{array}{c}0.79 \\
(0.54)\end{array}$ & $\begin{array}{c}0.71 \\
(1.12)\end{array}$ \\
\hline Protein content (\%) & $\begin{array}{l}0.09 \\
(0.004)\end{array}$ & $\begin{array}{l}0.11 \\
(0.004)\end{array}$ & $\begin{array}{c}0.12 \\
(0.008)\end{array}$ & $\begin{array}{l}0.12 \\
(0.004)\end{array}$ & $\begin{array}{l}0.10 \\
(0.004)\end{array}$ & $\begin{array}{l}0.05 \\
(0.008)\end{array}$ \\
\hline Fat yield (kg) & $\begin{array}{l}8.34 \\
(0.87)\end{array}$ & $\begin{array}{c}11.14 \\
(0.79)\end{array}$ & $\begin{array}{l}10.30 \\
(1.70)\end{array}$ & $\begin{array}{l}11.75 \\
(0.82)\end{array}$ & $\begin{array}{c}9.51 \\
(0.83)\end{array}$ & $\begin{array}{c}2.91 \\
(1.75)\end{array}$ \\
\hline Fat content $(\%)$ & $\begin{array}{c}0.24 \\
(0.01)\end{array}$ & $\begin{array}{c}0.34 \\
(0.009)\end{array}$ & $\begin{array}{c}0.38 \\
(0.02)\end{array}$ & $\begin{array}{c}0.38 \\
(0.009)\end{array}$ & $\begin{array}{l}0.27 \\
(0.009)\end{array}$ & $\begin{array}{c}0.10 \\
(0.02)\end{array}$ \\
\hline Lactose yield (g) & $\begin{array}{c}7.23 \\
(2.13)\end{array}$ & $\begin{array}{c}-0.09 \\
(1.94)\end{array}$ & $\begin{array}{r}-13.98 \\
(4.13)\end{array}$ & $\begin{array}{c}-4.80 \\
(2.03)\end{array}$ & $\begin{array}{c}5.19 \\
(2.06)\end{array}$ & $\begin{array}{l}13.54 \\
(4.34)\end{array}$ \\
\hline Lactose content (\%) & $\begin{array}{l}-0.03 \\
(0.003)\end{array}$ & $\begin{array}{l}-0.04 \\
(0.003)\end{array}$ & $\begin{array}{l}-0.03 \\
(0.005)\end{array}$ & $\begin{array}{l}-0.03 \\
(0.003)\end{array}$ & $\begin{array}{l}-0.04 \\
(0.003)\end{array}$ & $\begin{array}{l}-0.04 \\
(0.006)\end{array}$ \\
\hline Milk energy yield (ME) & $\begin{array}{c}1.56 \\
(0.14)\end{array}$ & $\begin{array}{c}1.61 \\
(0.13)\end{array}$ & $\begin{array}{c}1.24 \\
(0.27)\end{array}$ & $\begin{array}{c}1.63 \\
(0.13)\end{array}$ & $\begin{array}{c}1.56 \\
(0.14)\end{array}$ & $\begin{array}{c}1.12 \\
(0.28)\end{array}$ \\
\hline Milk energy content (ME/kg) & $\begin{array}{c}-0.005 \\
(0.006)\end{array}$ & $\begin{array}{l}0.06 \\
(0.006)\end{array}$ & $\begin{array}{c}0.13 \\
(0.01)\end{array}$ & $\begin{array}{c}0.10 \\
(0.005)\end{array}$ & $\begin{array}{c}0.01 \\
(0.006)\end{array}$ & $\begin{array}{c}-0.10 \\
(0.01)\end{array}$ \\
\hline SCS & $\begin{array}{c}-0.03 \\
(0.01)\end{array}$ & $\begin{array}{c}-0.02 \\
(0.01)\end{array}$ & $\begin{array}{c}-0.03 \\
(0.02)\end{array}$ & $\begin{array}{c}-0.03 \\
(0.01)\end{array}$ & $\begin{array}{c}-0.03 \\
(0.01)\end{array}$ & $\begin{array}{c}-0.01 \\
(0.01)\end{array}$ \\
\hline
\end{tabular}

regression variables were significant (in all cases $P<$ 0.02 ) when the haplotype $\mathrm{KE}$ was included in the model. The estimated regression coefficient for haplotype KE was negative (not shown), indicating that the positive effects of the $\mathrm{K}$ variant and the VNTR allele $\mathrm{E}$ were smaller for daughters carrying copies of both alleles (Table 4).

A statistical significant interaction between the haplotypes $\mathrm{KE}$ and $\mathrm{KO}$ was detected for milk energy content $(P=0.03$, results of model [6]). More specifically, the effect of the haplotype $\mathrm{KE}$ was only significant for those daughters that did not carry a copy of the haplotype KO $(P<0.001)$.

\section{Allele Substitution Effects of the CSN1S1 Promoter}

The multiple regression model [7] on the different number of copies of the alleles at the CSN1S1 promoter indicated that the allele substitution effects of the alleles 2 and 3 on the yield traits milk, protein, fat, lactose, and milk energy yield, as well as milk energy content showed both statistically significant effects but in the opposite direction (Table 7). For example, the CSN1S1 allele 2 showed an allele substitution effect of $\alpha=-0.37$ for the trait milk energy yield $(P=0.02)$, whereas the CSN1S1 allele 3 affected this trait in a positive way ( $\alpha=0.56 ; P=0.004$ ). Neither the $C S N 1 S 1$ allele 2 nor the CSN1S1 allele 3 showed any significant effects for content traits or SCS. Additionally no significant interactions between CSN1S1 and DGAT1 K232A could be observed (no significant results for the interaction term in model [9]).

\section{DISCUSSION}

\section{Allele Frequencies for DGAT1 K232A}

The estimated allele frequency of 0.61 for the $\mathrm{K}$ variant at DGAT1 K232A in the German Angeln dairy cattle population was identical to the frequencies reported by Kaupe et al. (2004) for the same breed, but higher than those reported for Holstein-Friesians. Thaller et al. (2003) reported an allele frequency in the German Holstein population of 0.55 . Other studies in the Holstein population and in the Polish Black and White population estimated allele frequencies between 0.30 and 0.68 (Bovenhuis and Schrooten, 2002; Winter et al., 2002; Pareek et al., 2005). The K frequency in the German Fleckvieh population was substantially lower $(0.07$; Thaller et al., 2003). The relatively high frequency of the $\mathrm{K}$ variant in the German Angeln population could be due to the selection on content traits in former years, which is the same for the Jersey population. This was supported in the present study by the fact that 2 sires were homozygous for the $\mathrm{K}$ variant and that none of the sires was homozygous for the A variant. The population mean of the fat content in the Jersey breed was even higher compared with the German Angeln breed and the $\mathrm{K}$ frequency was also somewhat higher in the Jerseys (between 0.69 and 0.88; Spelman et al., 2002; Winter et al., 2002; Kaupe et al., 2004).

\section{Allele Substitution Effects of DGAT1 K232A and of the DGAT1 Promoter VNTR}

The estimated allele substitution effects of DGAT1 K232A on the milk production traits in the German 
Table 7. Allele substitution effects $(\alpha)$, standard errors (SE), and $P$-values of the alleles 2 and 3 at the CSN1S1 promoter compared with the other alleles on 10 milk production traits (results of model [8])

\begin{tabular}{|c|c|c|c|c|c|c|}
\hline \multirow[b]{2}{*}{ Trait } & \multicolumn{3}{|c|}{ CSN1S1 allele 2} & \multicolumn{3}{|c|}{ CSN1S1 allele 3} \\
\hline & $\alpha$ & $\mathrm{SE}$ & $P$-value & $\alpha$ & $\mathrm{SE}$ & $P$-value \\
\hline Milk yield (kg) & -35.85 & 18.38 & 0.05 & 51.10 & 22.31 & 0.020 \\
\hline Protein yield (kg) & -1.21 & 0.63 & 0.06 & 1.95 & 0.77 & 0.010 \\
\hline Protein content (\%) & $<0.01$ & 0.01 & 0.71 & $<0.01$ & 0.01 & 0.800 \\
\hline Fat yield (kg) & -1.92 & 0.98 & 0.05 & 2.10 & 1.18 & 0.080 \\
\hline Fat content (\%) & $<-0.01$ & 0.01 & 0.95 & -0.01 & 0.01 & 0.520 \\
\hline Lactose yield (g) & -6.38 & 2.45 & 0.01 & 9.52 & 2.97 & 0.001 \\
\hline Lactose content (\%) & $<-0.01$ & $<0.01$ & 0.44 & $<-0.01$ & 0.01 & 0.660 \\
\hline Milk energy yield (ME) & -0.37 & 0.16 & 0.02 & 0.56 & 0.19 & 0.004 \\
\hline Milk energy content (ME/kg) & 0.01 & 0.01 & 0.30 & -0.01 & 0.01 & 0.090 \\
\hline SCS & -0.01 & 0.01 & 0.33 & 0.02 & 0.02 & 0.230 \\
\hline
\end{tabular}

Angeln population were substantially lower than those in the German Holstein population, but they affected the different traits in the same direction (Table 3; Thaller et al., 2003; Bennewitz et al., 2004). Spelman et al. (2002) reported almost the same effects for the $\mathrm{K}$ variant in the New Zealand Jersey population as observed in the German Angeln population. One reason for lower allele substitution effects in the Angeln and the Jersey breeds could be that both breeds showed higher population means for the content traits. Additionally, the influence of the $\mathrm{K}$ variant did not affect the content traits on the same level as in the Holstein Friesian breed, because of a higher base level of the triglyceride synthesis in these breeds. The limiting factor for a higher triglyceride synthesis might be the limited availability of the 2 substrates (diacylglycerol and fatty acyl-CoA) in the final step of the triglyceride synthesis. To investigate this in more detail, the data set was split into 2 subsets with daughters that had fat content below or above the overall mean. Both parts were analyzed separately by model [1]. The results showed that the DGAT1 K232A substitution effect was almost twice as large for the first part compared with the corresponding effect of the second part (not shown) supporting the hypothesis described above. It can be also interpreted as an interaction of DGAT1 with background genes, which may compete for substrates.

The $\mathrm{K}$ variant at DGAT1 K232A showed no significant effects for the milk energy yield but highly significant effects for the yield traits milk, protein, and fat. Hence, DGAT1 K232A behaved neutrally with regard to the milk energy yield. This neutral character is due to the redistribution of the milk energy of the cow between the 3 milk components fat, protein, and lactose depending on the corresponding DGAT1 K232A genotype.

It was observed that the VNTR allele E showed significant effects for some milk production effects compared with all other alleles at the DGAT1 promoter
VNTR. The same results were reported by Kühn et al. (2004) for the DGAT1 VNTR allele 5. However, in contrast to Kühn et al. (2004), the VNTR allele E was mainly linked to the $\mathrm{K}$ variant at DGAT1 K232A (Table 2 ), whereas the DGAT1 VNTR allele 5 showed up with the A variant in the German Holstein Friesian population (Kühn et al., 2004). It is likely that the VNTR allele E corresponds to the DGAT1 VNTR allele 5 of Kühn et al. (2004), but it was not possible to verify this. An interesting point was the significance of DGAT1 K232A and the promoter VNTR for SCS and lactose content (results of model [3]; Table 4). This could not be observed for DGAT1 K232A without the promoter VNTR in the model (results of model [1]; Table 3), probably because of the opposite direction of the $\mathrm{K}$ variant and the VNTR allele $\mathrm{E}$ and hence, of the neutral effect of haplotype $\mathrm{KE}$ on these traits (Table 5). Consequently, both mutations may also affect udder health in dairy cattle. Additionally, whereas the $\mathrm{K}$ variant and the VNTR allele $\mathrm{E}$ affected the milk production traits in the same direction, this was not the case for udder health.

For daughters with the haplotypes $\mathrm{KE}, \mathrm{AE}$, and $\mathrm{KO}$, it was shown that the effects on the different milk production traits were in general in the same direction (Table 5). Compared with the haplotype KO, the haplotype KE showed substantially larger effects for milk yield and protein yield and protein content. For example for milk yield, the effect of the haplotype KO was $\alpha=$ $-19.75(P=0.34)$ and the effect of the haplotype KE was $\alpha=-73.19(P<0.001)$. The comparison of the effects of the haplotypes $\mathrm{AE}$ and $\mathrm{AO}$ emphasizes the strong effect of the VNTR allele E. Despite the opposite effects of the A variant at DGAT1 K232A and the VNTR allele $\mathrm{E}$, the effects of the haplotype $\mathrm{AE}$ were determined by the effects of the VNTR allele E. This was illustrated, for example, by the effects on protein yield, in which the haplotype AO showed a positive effect $(\alpha=1.49$, $P=0.007$ ), whereas the haplotype AE showed a negative effect ( $\alpha=-7.12, P=0.04)$. Consequently, daughters 
with the haplotype $\mathrm{AE}$ showed the same phenotype as daughters with the haplotype KE. It should be noted that the presented results, especially for the haplotype $\mathrm{AE}$, were not always significant either because of the low frequency of this haplotype (Table 2) or because it had no or little effect. In general, it would be beneficial to have more balanced data structure to unravel this and also to contrast the effects of the haplotypes with higher accuracy. Model [2] revealed significant effects of allele E compared with all other alleles at DGAT1 VNTR and consequently, the other alleles were pooled in subsequent analysis. However, with more balanced data structure and possibly with more equal allele frequencies, differences between the effects of the DGAT1 VNTR alleles may also be detected.

The effects of the DGAT1 K232A and the DGAT1 promoter VNTR did not act strictly additively. This became obvious by comparing the effects of the mutations separately (Table 4) and in combination (Table 5 ), and additionally the least squares means in Table 6 . For example, the effects of the $\mathrm{K}$ variant and of the VNTR allele $\mathrm{E}$ on fat content were $\alpha=0.12$ and $\alpha=$ 0.007 , respectively (Table 4 ), but the effect of the haplotype $\mathrm{KE}$ was not the sum of both but only $\alpha=0.09$. Additionally, the effects of the haplotypes $\mathrm{KE}, \mathrm{AO}$, and KO were on a similar level for this trait (Table 5). Hence, it seems that there was an upper physiological boundary for the effect, especially for fat content, due to the haplotypes, and this limit was reached by both the $\mathrm{K}$ variant and the VNTR allele $\mathrm{E}$, regardless of the allele of the respective other mutation (DGAT1 K232A and promoter VNTR, respectively). The nonstrict additive behavior of these 2 mutations for fat content was also formally shown by the statistical significance of the interaction test (results of model [5]) and by the results of the haplotype interaction model for milk energy content (results of model [6]).

\section{Effects on BTA6 Affected by the CSN1S1 Promoter}

The allele frequencies at the CSN1S1 promoter were on a similar level as that reported in German Holsteins (Table 1; Prinzenberg et al., 2003). Opposite results to those reported by Prinzenberg et al. (2003) were observed for the substitution effects of the included alleles at the CSN1S1 promoter. In the Angeln population, significant allele substitution effects were found for the yield traits, either for CSN1S1 alleles 2 or 3, whereas no significant effects were observed for the content traits and SCS. Prinzenberg et al. (2003) found only significant allele substitution effects for protein content and suggested that the CSN1S1 allele 4 affected this trait in a positive way. This effect was not confirmed in the present study. This discrepancy could be due to the small number of daughters carrying this allele in the Angeln population (low frequency of CSN1S1 allele 4, Table 1). On the basis of the study of Prinzenberg et al. (2003) and the present study, it remains to be investigated if the CSN1S1 promoter could be a functional candidate locus for the trait protein content as discussed by Prinzenberg et al. (2003). Another hypothesis is that the observed effects are due to linkage disequilibrium between the CSN1S1 promoter and the causative mutation.

\section{CONCLUSIONS}

The allele substitution effects on milk production traits of the DGAT1 K232A mutation, the DGAT1 promoter VNTR, the respective DGAT1 haplotypes, and the CSN1S1 promoter were investigated in this study. Segregation of 6 alleles at the DGAT1 promoter VNTR and of 4 alleles at the CSN1S1 promoter was found in the Angeln population. Besides DGAT1 K232A, one allele of the $D G A T 1$ promoter VNTR showed significant effects on lactose yield and content, milk energy content, and SCS. No dominance effect for DGAT1 K232A was observed. A nonstrict additivity of the effects of DGAT1 K232A and DGAT1 promoter VNTR haplotypes was found, probably due to an upper physiological limit of the effects for fat yield and content due to the DGAT1 gene. Furthermore, significant allele substitution effects were observed for 2 alleles at the CSN1S1 promoter for the milk yield.

\section{ACKNOWLEDGMENTS}

This study was supported by the Foundation Schleswig-Holsteinische Landschaft. We gratefully thank I. Raeder (FBN Dummerstorf) for excellent assistance in preparing lactose and milk energy data and $\mathrm{H}$. Kluding, J. Brakel, I. Rix, B. Mohrmann, and G. Ottzen-Schirakow for excellent assistance and helpful comments during the laboratory work.

\section{REFERENCES}

Bennewitz, J., N. Reinsch, and E. Kalm. 2002. GENCHECK: A program for consistency checking and derivation of genotypes at codominant and dominant loci. J. Anim. Breed. Genet. 119:350-360.

Bennewitz, J., N. Reinsch, S. Paul, C. Looft, B. Kaupe, C. Weimann, G. Erhardt, G. Thaller, Ch. Kühn, M. Schwerin, H. Thomsen, F. Reinhardt, R. Reents, and E. Kalm. 2004. The DGAT1 K232A mutation is not solely responsible for the milk production quantitative trait locus on the bovine chromosome 14. J. Dairy Sci. $87: 431-442$.

Bovenhuis, H., and C. Schrooten. 2002. Quantitative trait loci for milk production traits in dairy cattle. No. 09-07 in Proc. 7th World Congr. Genet. Appl. Livestock Prod., Montpellier, France. 31:27-34.

Falconer, D. S., and T. F. C. Mackay. 1996. Introduction to Quantitative Genetics. 4th ed. Longman Scientific and Technical, New York, NY. 
Farnir, F., B. Grisart, W. Coppieters, J. Riquet, P. Berzi, N. Cambisano, L. Karim, M. Mni, S. Moisio, P. Simon, D. Wagenaar, J. Vilkki, and M. Georges. 2002. Simultaneous mining of linkage and linkage disequilibrium to fine map quantitative trait loci in outbred half-sib pedigrees: Revisiting the location of a quantitative trait locus with major effect on milk production on bovine chromosome 14. Genetics 161:275-287.

Grisart, B., W. Coppieters, F. Farnir, L. Karim, C. Ford, P. Berzi, N. Cambisano, M. Mni, S. Reid, P. Simon, R. Spelman, M. Georges, and R. Snell. 2002. Positional candidate cloning of a QTL in dairy cattle: Identification of a missense mutation in the bovine DGAT1 gene with major effect on milk yield and composition. Genome Res. 12:222-231.

Grisart, B., F. Farnir, L. Karim, N. Cambisano, J.-J. Kim, A. Kvasz, M. Mni, P. Simon, J.-M. Frère, W. Coppieters, and M. Georges. 2004. Genetic and functional confirmation of the causality of DGAT1 K232A quantitative trait nucleotide in affecting milk yield and confirmation. Proc. Natl. Acad. Sci. USA 101:2398-2403.

Kaupe, B., A. Winter, R. Fries, and G. Erhardt. 2004. DGAT1 polymorphism in Bos indicus and Bos taurus cattle breeds. J. Dairy Res. 71:182-187.

Khatkar, M. S., P. C. Thomson, I. Tammen, and H. W. Raadsma. 2004. Quantitative trait loci mapping in dairy cattle: Review and meta-analysis. Genet. Sel. Evol. 36:163-190.

Kühn, Ch., G. Thaller, A. Winter, O. R. P. Bininda-Emonds, B. Kaupe, G. Erhardt, J. Bennewitz, M. Schwerin, and R. Fries. 2004. Evidence for multiple alleles at the DGAT1 locus better explains a quantitative trait locus with major effect on milk fat content in cattle. Genetics 167:1873-1881.

Kuss, A. W., J. Gogol, H. Bartenschlager, and H. Geldermann. 2005. Polymorphic AP-1 binding site in bovine CSN1S1 shows quantitative differences in protein binding associated with milk protein expression. J. Dairy Sci. 88:2246-2252.

Nostitz, B., and H. Mielke. 1995. Vergleich verschiedener Methoden der Bestimmung des Milchenergiegehaltes beim Schwarzbunten Milchrind. J. Anim. Physiol. A. Anim. Nutr. 73:9-18.

Olsen, H. G., S. Lien, M. Gautier, H. Nilsen, A. Roseth, P. R. Berg, K. K. Sundsaasen, M. Svendsen, and T. H. E. Meuwissen. 2005. Mapping of a milk production quantitative trait locus to a 420 $\mathrm{kb}$ region on bovine chromosome 6. Genetics 169:275-283.

Pareek, C. S., U. Czarnik, T. Zabolewicz, R. S. Pareek, and K. Walawski. 2005. DGAT1 K232A quantitative trait nucleotide polymorphism in Polish Black-and-White cattle. J. Appl. Genet. 46:85-87.

Prinzenberg, E.-M., C. Weimann, H. Brandt, J. Bennewitz, E. Kalm, M. Schwerin, and G. Erhardt. 2003. Polymorphism of the CSN1S1 promoter: Linkage mapping, intragenic haplotypes, and effects on milk production traits. J. Dairy Sci. 86:2696-2705.
Reinsch, N. 1999. A multiple-species, multiple-project database for genotypes at codominant loci. J. Anim. Breed. Genet. 116:425435.

Riquet, J., W. Coppieters, N. Cambisano, J.-J. Arranz, P. Berzi, S. K. Davis, B. Grisart, F. Farnir, L. Karim, M. Mni, P. Simon, J. F. Taylor, P. Vanmanshoven, D. Wagenaar, J. E. Womack, and M. Georges. 1999. Fine-mapping of quantitative trait loci by identity by descent in outbred populations: Application to milk production in dairy cattle. Proc. Natl. Acad. Sci. USA 96:9252-9257.

Ron, M., D. Kliger, E. Feldmesser, E. Seroussi, E. Ezra, and J. I. Weller. 2001. Multiple quantitative trait locus analysis of bovine chromosome 6 in the Israeli Holstein population by a daughter design. Genetics 159:727-735.

Rozen, S., and H. S. Skaletsky. 2000. Primer3 on the www for general users and for biologist programmers. Pages 365-386 in Bioinformatics Methods and Protocols: Methods in Molecular Biology. S. Krawetz and S. Misener, ed. Humana Press, Totowa, NJ. http:// frodo.wi.mit.edu/cgi-bin/primer3/primer3_www.cgi

Sanders, K., J. Bennewitz, and E. Kalm. 2006. Wrong and missing sire information affect the genetic gain in the German Angeln dairy cattle population. J. Dairy Sci. 89:315-321.

Savaş, T., N. Reinsch, and E. Kalm. 1998. Auswirkungen der Rassenzusammensetzung auf Merkmale der Tagesmilchmenge und auf die Zellzahl beim Angler Rind. Arch. Tierzucht. 41:201-209.

Spelman, R. J., C. A. Ford, P. McElhinney, G. C. Gregory, and R. G. Snell. 2002. Characterization of the DGAT1 gene in the New Zealand dairy population. J. Dairy Sci. 85:3514-3517.

Thaller, G., W. Krämer, A. Winter, B. Kaupe, G. Erhardt, and R. Fries. 2003. Effects of DGAT1 variants on milk production traits in German cattle breeds. J. Anim. Sci. 81:1911-1918.

Velmala, R. J., H. J. Vilkki, K. T. Elo, D. J. deKoning, and A. V. Mäki-Tanila. 1999. A search for quantitative trait loci for milk production traits on chromosome 6 in Finnish Ayrshire cattle. Anim. Genet. 30:136-143.

VIT. 2003. Zuchtwertschätzung, Vereinigte Informationssysteme Tierhaltung w.V., Verden/Aller, Germany. http://www.vit.de

Wiggans, G. R., and P. M. VanRaden. 1991. Method and effect of adjustment for heterogeneous variance. J. Dairy Sci. 74:43504357.

Winter, A., W. Krämer, F. A. O. Werner, S. Kollers, S. Kata, G. Durstewitz, J. Buitkamp, J. E. Womack, G. Thaller, and R. Fries. 2002. Association of a lysine-232/alanine polymorphism in a bovine gene encoding acyl-CoA:diacylglycerol acyltransferase (DGAT1) with variation at a quantitative trait locus for milk fat content. Proc. Natl. Acad. Sci. USA 99:9300-9305.

\section{APPENDIX}

\section{A: Estimation of the Variance of the Yield Deviations}

The yield deviations for the first 3 lactations were used as phenotypes. They were combined into one value $\left(\mathrm{YD}_{1 .-3 . \text { lactation }}\right)$ by weighting the 3 yield deviations as follows:

$$
\mathrm{YD}_{1 .-3 . \text { lactation }}=\mathbf{w}^{\prime} \mathbf{y} \text {, }
$$

where $\mathbf{w}^{\prime}=$ a vector of the weights for the 3 lactations; i.e., $\mathbf{w}^{\prime}=\left[\begin{array}{lll}\mathrm{w}_{1} & \mathrm{w}_{2} & \mathrm{w}_{3}\end{array}\right]$, and $\mathbf{y}=$ a vector with the yield deviations of the corresponding lactation; i.e., $\mathbf{y}^{\prime}=\left[\mathrm{YD}_{1} \mathrm{YD}_{2} \mathrm{YD}_{3}\right]$. The values $\mathrm{w}_{1}$ to $\mathrm{w}_{3}$ were calculated as the number of the test milkings in the respective lactation $\left(\mathrm{n}_{1}, \mathrm{n}_{2}\right.$, and $\mathrm{n}_{3}$, respectively) divided by the total number of test milkings (i.e., $\mathrm{n}_{1}+\mathrm{n}_{2}+\mathrm{n}_{3}$ ). The variances of the $\mathrm{YD}_{1 .-3 . \text { lactation were estimated as: }}$

$$
\operatorname{Var}\left(\mathrm{YD}_{1 .-3 . \text { lactation }}\right)=\mathbf{w}^{\prime} \mathbf{V} \mathbf{w}
$$

where $\mathbf{V}$ represents the variance-covariance matrix of the yield deviations in the 3 lactations. This matrix can be written as: 


$$
\mathbf{V}=\operatorname{Var}\left[\begin{array}{c}
\mathrm{YD}_{1} \\
\mathrm{YD}_{2} \\
\mathrm{YD}_{3}
\end{array}\right]=\left[\begin{array}{lll}
\left(\sigma_{\mathrm{a} 1}^{2}+\sigma_{\mathrm{p} 1}^{2}+\frac{1}{\mathrm{n}_{1}} \sigma_{\mathrm{e} 1}^{2}\right) & \left(\sigma_{\mathrm{a} 1, \mathrm{a} 2}+\sigma_{\mathrm{p} 1, \mathrm{p} 2}\right) & \left(\sigma_{\mathrm{a} 1, \mathrm{a} 3}+\sigma_{\mathrm{p} 1, \mathrm{p} 3}\right) \\
\left(\sigma_{\mathrm{a} 1, \mathrm{a} 2}+\sigma_{\mathrm{p} 1, \mathrm{p} 2}\right) & \left(\sigma_{\mathrm{a} 2}^{2}+\sigma_{\mathrm{p} 2}^{2}+\frac{1}{\mathrm{n}_{2}} \sigma_{\mathrm{e} 2}^{2}\right) & \left(\sigma_{\mathrm{a} 2, \mathrm{a} 3}+\sigma_{\mathrm{p} 2, \mathrm{p} 3}\right) \\
\left(\sigma_{\mathrm{a} 1, \mathrm{a} 3}+\sigma_{\mathrm{p} 1, \mathrm{p} 3}\right) & \left(\sigma_{\mathrm{a} 2, \mathrm{a} 3}+\sigma_{\mathrm{p} 2, \mathrm{p} 3}\right) & \left(\sigma_{\mathrm{a} 3}^{2}+\sigma_{\mathrm{p} 3}^{2}+\frac{1}{\mathrm{n}_{3}} \sigma_{\mathrm{e} 3}^{2}\right)
\end{array}\right],
$$

where $\sigma_{\mathrm{aj}}^{2}, \sigma_{\mathrm{pj}}^{2}$, and $\sigma_{\mathrm{ej}}^{2}$ are the additive genetic, permanent environment, and residual variance of lactation $\mathrm{j}$, and $\sigma_{\mathrm{aj}, \mathrm{aj} j^{\prime}}$ and $\sigma_{\mathrm{pj}, \mathrm{pj}}$ being the covariance of the additive genetic and permanent environment variance of lactation $\mathrm{j}$ and $\mathrm{j}^{\prime}\left(\mathrm{j} \neq \mathrm{j}^{\prime}\right)$. The variance components were taken from unpublished data of N. Reinsch and J. Bennewitz.

\section{B: Calculation of the Posterior Probability}

Posterior probabilities for the haplotypes were used in the statistical analysis for daughters, whose haplotypes of the DGAT1 K232A mutation and the DGAT1 promoter VNTR could not be unequivocally derived. The calculation of the posterior probability will be demonstrated by an example: The haplotype of DGAT1 K232A and the $D G A T 1$ promoter VNTR of a sire was $\mathrm{KC}$ and $\mathrm{KD}$. The 2 possibilities for the haplotypes of a daughter, if the daughter had the genotypes AK for DGAT1 K232A and CD for the DGAT1 promoter VNTR, were AC and KD or $\mathrm{AD}$ and $\mathrm{KC}$. In the first case, the daughters inherited the haplotype $\mathrm{AC}$ from the population, whereas in the second case, they inherited the haplotype $\mathrm{AD}$. The posterior probability for the first possibility was:

$$
\mathrm{p}_{1}=\frac{0.5 \mathrm{f}(\mathrm{AC})}{(0.5 \mathrm{f}(\mathrm{AC}))+(0.5 \mathrm{f}(\mathrm{AD}))},
$$

where $\mathrm{f}(\mathrm{AC})$ and $\mathrm{f}(\mathrm{AD})=$ the population frequencies of the haplotypes $\mathrm{AC}$ and $\mathrm{AD}$, respectively. These population frequencies were estimated analogue to the allele frequencies by a maximum likelihood approach that is tailored to a half-sib pedigree structure (Sanders et al., 2006). The posterior probability for the second possibility was: $\mathrm{p}_{2}=1-\mathrm{p}_{1}$. 